\title{
The Influence of Leadership And Organizational Culture To Motivation And Employee Performance At University of Nahdlatul Ulama Surabaya Indonesia
}

\author{
Dr. Ir. Djoko Soelistya, MM \\ University of Nahdatul Ulama in Surabaya, Indonesia \\ Ir. Ahmad Gamal, SE, MM \\ University of WR. Supratman Surabaya, Indonesia
}

\begin{abstract}
The role of human resources experienced very significant changes as a result of the existence of an increasingly complex environment changes. Globalization, development of information technology, democracy and freedom of the mass media is the driving part of the environment, so the complexity demanded of the organization or institution to always think of ways how to be able to adapt and even addressing environmental change so that capable and can continue to make operational organization. Then to address such environmental changes, organization or College must have the support of a qualified human resources and competent as well as adhere to the value of innovative, professional, open and flexible. Employee is deciding who becomes a resource for College success, because the achievements of an organization are not in spite of the achievements as well as the role of members who are involved in it. This research aims to demonstrate and analyze the influence of leadership and organizational culture to motivation and employee performance University of Nahdatul Ulama in Surabaya. The sample in the research this is the employee University of Nahdatul Ulama in Surabaya totaled 62 people. Method of data processing is using SEM (Equational Structure Modeling) with AMOS version 18. The result of discussions can be concluded that 1) Leadership significant effect on employee motivation University of Nahdatul Ulama Surabaya, 2) Organizational culture significant effect on employee motivation University of Nahdatul Ulama Surabaya, and 3) Motivation significant effect on the employee performance University of Nahdatul Ulama in Surabaya.
\end{abstract}

Keywords: leadership, organizational culture, motivation and employee performance

\section{INTRODUCTION}

The company's performance is usually focused on the group task, rather than the group matter subject internally. It can be concluded from as a result of the implementation strategy of the college in order to realize its vision (Gamal and Soemantri, 2017: 127). Any institution or company always expect employees to have accomplishments, because by having employees who Excel will give a donation that is optimal for the company or institution. Via employees who perform College can improve its performance. Problems that often at a private University is facing problems regarding its human resources. Human resource issues into its own challenges for management due to the success of management and others it depends on the quality of its human resources. When individuals within an agency or company that is able to run human resources effective College then keep it running effectively. In other words the continuity of an agency or company that's determined by the performance of its employees. performance is the result of work in the quality and quantity is achieved by an officer in carrying out his duties in accordance with the responsibilities given to him (Mangkunegara, 2004:67). 
Factors affecting performance is the ability and a motivation factors Mangkunegara (2004). Any organization or company will seek to improve the performance of employees to achieve organizational goals that have been set. Various ways to improve the performance is employee. For many people especially the educated and capable of good, one purpose of the work is obtained performance. Conditions of work achievement or performance will be achieved when there is in the work of a non physical work environment that is conducive, has a strong individual character to always go forward and has sufficient self leadership.

Humans need the expertise of organizational culture rather than just those who occupy the top position in the organization. Expertise in the field of human culture of the Organization should be an integral part of that for the whole organization get to the level where the team harmony, interaction, and a corporate commitment to achieve its goal will determine success or failure. On private colleges that are high-performing increasingly seek to change their attention to the need for the service of process procedures such as organizational culture and the implementation of service auction and other achievements. They do the work flow reengineering toward forming the cross-functional team responsible for each process a successful organization is an organization that has a very good ability in managing the process of the implementation of the tasks and function.

Another factor that affects performance is the motivation, through employee motivation can be more active in work and have high discipline so that it is able to improve its performance. Motivation to become a benchmark to become successful employees or vice versa. Employees working with have a high motivation to raise a family. Its impact in the work of employees more seriously, always looking to improve its performance and always keep can work forever. Motivation is also the structure of a system that examines the function of the interaction between components and also its impact on the system. It can be said that motivation be capital for employees to be able to work well and high-performing. Based on explanation above, the authors are interested in researching the influence of the leadership and organizational culture of employee motivation and performance against the University of Nahdatul Ulama Surabaya.

\section{Leadership}

\section{LITERATURE REVIEW}

Leadership is defined as the ability to affect a group of people for the achievement of a vision or a set of goals (Robbins and Judge, 2009). DuBrin (2005:3) suggests that it is the leadership efforts affect many people through communication to achieve the goal, how to influence people with instructions or commands, actions that cause others to act or respond and cause positive changes, the dynamic power of the important motivating and coordinating organization in order to achieve the goal, the ability to create a sense of confidence and support among subordinates so that organizational goals can be achieved.

Leaders have always had the characteristics of an attempt to create a new one (always innovating). Ideas shared by leaders is the idea itself does not replicate or plagiarized. A leader always strives to develop what he was doing. He believed in subordinates, and always light a fire of confidence in members of the organization. The idea is to have a long-term perspective. He asked his subordinates with the question what and why. He is against the status quo, he is not satisfied with what is. He is responsible for what is done by his subordinates, and he exercised that right. 
Each leader has a leadership style, there are times when leaders do not give the opportunity on his subordinates to ask or ask for explanations (Authoritarian), there are times when the leader gives subordinates a chance to discuss, ask (Democratic), and there are times when leaders were letting conditions up to subordinates (Luthans, 2002:577). Leadership aimed at the completion of the task or goal orientation on (Initiating Structure), and the recognition of individual needs and relationships (Consideration). Leadership that is a concern for the employees (employee-centered) and also his concern for the production process.

Leadership is an activity to affect people in order that directed the Organization's objectives (Handoko, 2001), an indicator of leadership as follows: 1) Leaders provide a watchful eye, 2) Leaders of trying to explain the purpose of the tasks that must be done, 3) Leaders provide direction and support to subordinates, 4) Leaders provide the impetus to subordinates to use capabilities, 5) Leaders foster a two-way communication and 6) The chairman gave a boost to the morale of subordinates.

\section{Organizational culture}

Robbins (2002:247) States that the organizational culture is a shared definition of the system formed by the citizens as well as becoming the criterion with other organizations. There are seven characteristics are given. Some definitions of "organizational culture" expressed by experts, Schein (1992) formulated the "organizational culture" as: "A pattern of hared basic assumptions that the group learned as it solved its problem of external adaptation and internal integration, that has worked wenenough to be considered valid and therefore, to be laughl to new members as the correct way to perceive, think, and feel in relation to those problems".

Definition of Schein organizational culture looked at this as a pattern of basic assumptions conceived together in an organizations especially in solving the problems facing these patterns become inevitable and socialized to new members in organizations. Organizational culture relates to how employees of the perception characteristics of the culture of an organization. Indicators variable organizational culture are set based on Robbins (2006:195) that is as follows: 1) Trying very hard to improve on past performance on the job, 2) Enjoying the competition and victory, 3) Enjoy a challenge difficult, 4) Enjoy when saddled with responsibilities and 5) Relationship that Carib with colleagues work 6. Enjoy working with others than working alone.

\section{Motivation}

According to Mathis (2006:113) factors that affect the performance of employees, namely the ability of the employee to the work, the level of effort that was poured out, and support organizations that he received. With respect to any other management function, activities of human resource management should be developed, evaluated, and modified if necessary so that they can contribute to the competitive performance of organizations and individuals in the workplace. Factors that affect employees in work, namely the ability of the employee to perform the job level of effort are poured, and support organizations.

Robbins (2015: 127) motivation is the process that explains about the strength, direction, and someone's perseverance in efforts to achieve the objectives. According to Liang Gie in Samsudin (2009:281), motivation is the work done by the Manager in providing inspiration, passion, and encouragement to others, in this case the employees, to take certain actions. The granting of this impetus aims to invigorate people or employees so that they are eager and able to achieve the results desired by the people. 
Motivation is a desire in a person that causes the person to act. As for the motivation of working indicators are: 1) Participation in the work provide and increase a sense of satisfaction, 2) Encourage complacency for the increasingly active participation in the work embodies, 3) always enter employment, 4) Willingness to work voluntarily increased and expanded, 5) Feel the losers if not signed in/not present and 6) Always compelled to convey suggestions for improved productivity and quality.

\section{Employee performance}

Performance is the result of work in the quality and quantity is achieved by an officer in carrying out his duties in accordance with the responsibilities given to him (Mangkunegara, 2004:67). Performance is the term given for the word performance in the United Kingdom, which stands for language of work, deeds. In a broader sense, the words performance is always used in words such as job performance or work performance which means the work or accomplishments. Management experts generally gave the sense of a performance as the work achievement and work productivity. Performance according to Rivai and Basri (2005:14) is the result or the person's overall success rate during a certain period in comparison with the task of carrying out a wide range of possibilities, such as a standard work, targets or goals or criteria specified in advance.

Performance or performance refers to the levels of achievement of tasks that make up a work of employees. Performance reflects how well an employee meets the requirements of a job, so that performance is measured in terms of results (Simamora, 2004:339). Mangkunegara (2002:67) is the result of work performance in quality and quantity achieved an employee in carrying out its duties in accordance with the responsibility which they provide. Therefore according to Mathis and Jackson (2002:78) has the dimensions of performance is different for each different type of job, because every job has a criteria.

Employee performance is a result achieved by the employee in his work according to a certain criteria. that applies to a particular job. Indicators to measure the performance of employees, namely: 1) the work I do in accordance with the standard of work, 2) the work I do on time, 3) target predetermined work successfully my laurels, 4) I am able to understand the tasks related to the job, 5) I have knowledge was able to complete the work assigned to superiors and 6) The employee is able to cooperate with colleagues.

\section{Analysis Model}

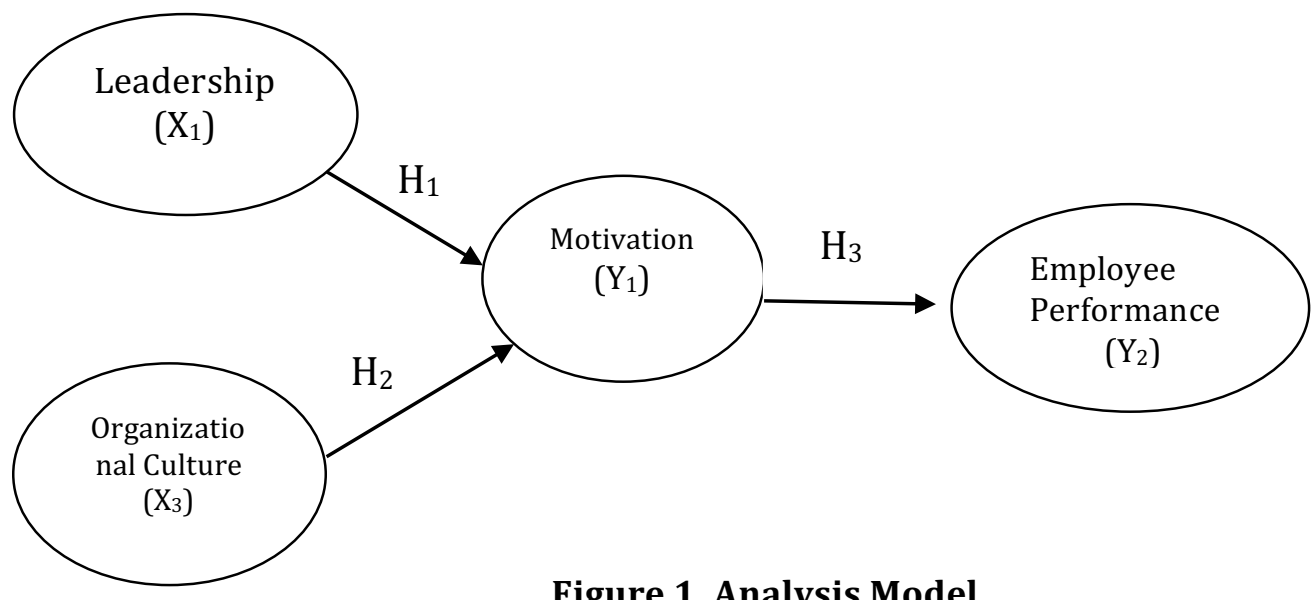

Figure 1. Analysis Model 


\section{Hypothesis}

H1: Leadership influence on employee motivation

H2: Organizational culture influence on employee motivation

H3: Motivation affects employee performance

\section{Research Stages}

\section{RESEARCH METHODS}

This study is begun by analyzing the perception of employee performance at the University of Nahdatul Ulama Surabaya that exists today. The number of samples in the study amounted to 62 employees University of Nahdatul Ulama Surabaya. The analysis is conducted using the method of participant observation, questionnaires, and interviews and processed with statistical program SEM (Structure Equational Modeling) using the AMOS version 18. Measurement techniques questionnaire using likert scale. This research uses of data analysis in SEM (Structure Equational Modeling) using the AMOS version 18 (Ferdinand, 2000:6).

According to Ghozali (2007:110), then the data is processed before data must first be tested with test of Normality. Test of normality is one of the conditions the data will be processed further.

\section{Data Analysis Technique}

Path analysis of Ferdinand (2000:324), there are stages of procedure formation of path analysis, namely:

1. Establish a model theory as a basis path analysis model which has a strong theoretical justification, which is a model of causal or cause damage declare the relationships between variables.

2. Build a path diagram of causal relationships that have been established on the basis of theory. Path diagrams are basic models used to analyze the paths for estimate strength of causal relationships illustrated in the diagram. In this research that became invalid constructs exogenous is leadership $\left(X_{1}\right)$ and organizational culture $\left(X_{2}\right)$. While endogenous invalid constructs (endogenous construct) are factors that predicted by one or more invalid constructs is the motivation $\left(\mathrm{Y}_{1}\right)$ and the performance of the employee $\left(\mathrm{Y}_{2}\right)$.

3. Convert the model into a series of equations. Amos programs will convert the image into the equation and the equation being estimated. Will be visible on the diagram of the path invalid constructs two groups namely exogenous and endogenous invalid constructs invalid constructs.

\section{ANALYSIS AND DISCUSSION}

UNUSA founded by Yayasan Islamic Hospital Surabaya (YARSIS). The embryo establishment dates back as early as 1979, namely in the form of the establishment of the nursing school health (SPK) YARSIS.. Don't stop until there, in 2006, 2 the institution (AKPER-AKBID) YARSIS do the Union institutions and conversion into STIKES YARSIS up to this time with the addition of the Undergraduate Nursing Program and the status of the profession of Ners. STIKES YARSIS that existed in Surabaya armed with more than 33 years of experience in managing educational institutions and encouragement of. A big leap but was routed from the long process, ultimately resulting in the year 2013 the University of Nahdlatul Ulama Surabaya (UNUSA). To facilitate 16 courses that have opened, the UNUSA has 2 campuses with complete facilities and modern. A fully equipped laboratory is supported for each course has its own hospital (RS. Islam Surabaya A. Yani and RS. Islam In Surabaya Jemursari).

Results analysis using SEM research model shown in Figure 1. A model is said to be good in the 
development of the conceptual and theoretical hypothesis supported by empirical data, structural equation model test results are shown on the following picture.

\section{Feasibility Test with Goodness of Fit Indices Model}

Based on the method of determining the value in the model, the first model testing variables are grouped into exogenous variables (leadership, organizational culture) and endogenous variables (motivation and employee performance). The contruct test results of the first model are evaluated based goodness of fit indices model. Criterion of models as well as critical values that have data consistency can be seen in Table 1 below.

Table 1. Evaluation Criteria Goodness of Fit Indices

\begin{tabular}{|l|c|c|c|}
\hline Goodness of Fit Measure & Cut of Value & Results Model & Specification \\
\hline Chi-square & Tiny expected & 75,021 & \\
\hline Significane Probability & $>0,05$ & 0,000 & Fit model \\
\hline RMSEA & $\leq 0,08$ & 0,091 & Marginal Fit \\
\hline GFI & $\geq 0,9$ & 0,855 & Fit model \\
\hline AGFI & $\geq 0,9$ & 0,050 & Marginal Fit \\
\hline CMIN/DF & $\leq 0,08$ & 0,042 & Fit model \\
\hline RMR & $\leq 0,05$ & 0,047 & Fit model \\
\hline TLI & $\geq 0,9$ & 0,915 & Fit model \\
\hline CFI & $\geq 0,9$ & 0,870 & Marginal Fit \\
\hline
\end{tabular}

Based on Table 1 it can be seen that the model fit for use with assume Parsemony principle fulfill the criteria because there is more than one meet so that the model is fit for use. Evaluation models show from of the eight criteria of goodness of fit indices all had met the criteria and was approaching the critical value suggested. Thus, referring to the principle of parsimony, the overall model can be said to have been in accordance with the data and it can be analyzed further. 


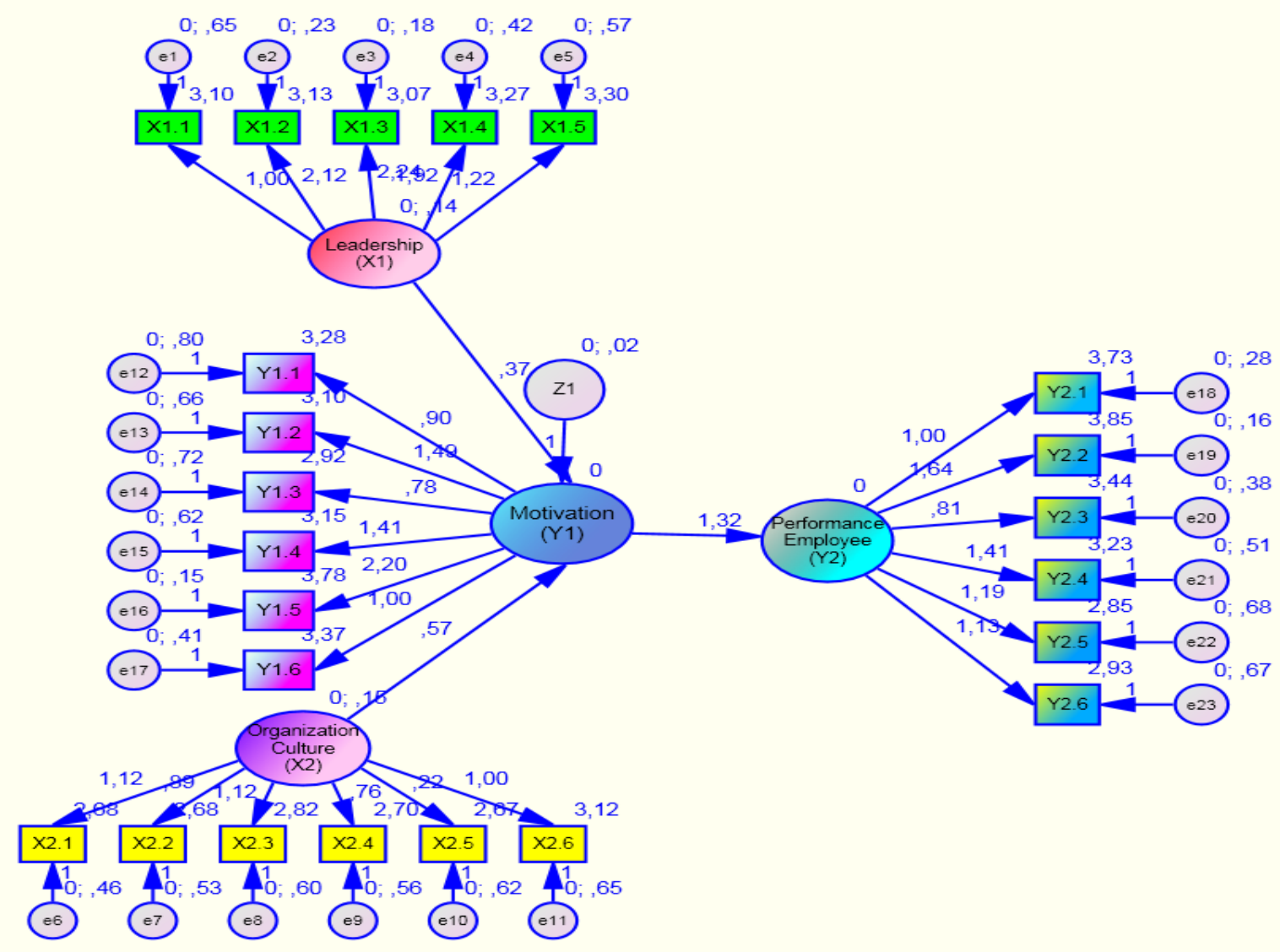

Figure 2. Structural Equation Model

Testing the hypothesis presented in this study was done based on the value of the Critical ratio of CR from a relationship of causality. The results of the analysis of the relationship of causality between the variables research using program AMOS version 18 can be seen in table 2 .

Table 2. Test Causality Regression Weight

\begin{tabular}{|c|c|c|c|c|c|c|}
\hline \multicolumn{3}{|c|}{ The Relationship of Causality } & Estimate & & CR & Significant \\
\hline Leadership_( $\left.\mathrm{X}_{1}\right)$ & $\rightarrow$ & Motivation_(Y $\left.Y_{1}\right)$ & ,367 & ,177 & 2,073 & ,038 \\
\hline Organization_Culture_( $\left(\mathrm{X}_{2}\right)$ & $\rightarrow$ & Motivation_( $\left.\mathrm{Y}_{1}\right)$ & ,567 & ,274 & 2,069 & 039 \\
\hline Motivation_(Y $\left.\mathrm{Y}_{1}\right)$ & $\rightarrow$ & $\begin{array}{l}\text { Employee } \\
\text { Performance } \\
\left(\mathrm{Y}_{2}\right)\end{array}$ & 1,323 & 483 & 2,741 & ,006 \\
\hline
\end{tabular}

\section{Hypothesis testing}

Based on the empirical model proposed in this study, it can be tested against the hypothesis put forward by testing the path coefficients in structural equation modeling. Data analysis presents the results of hypothesis testing to see critical ratio (CR) and p-value. 


\section{Leadership significant effect on motivation}

The results of the estimation of parameters of the variable leadership against employee motivation based on indicators show significant results with a value of CR 2.073. This value is greater than 1.96. Besides significance levels obtained $0.038(\mathrm{p}<0.05)$. So the first hypothesis stating the influential leadership significantly to current motivation proved to be true.

According to Arif (2010) that the leadership is the ability of a leader to influence subordinates or employees to work performing actions or activities that relate to accomplish a goal. The results of the research shows that the leadership of the effect on the performance of employees. According to Idham and Subowo (2005), found the results positively influential leadership against the performance of employees. Employees who have a fair and wise leadership, giving direction on when giving orders, and can work together with the employee, then it will result in better performance.

\section{Organizational culture significant effect on motivation}

he results of the estimation of parameters of the variable organizational culture towards employee motivation based on indicators show significant results with a value of CR 2.069. This value is greater than 1.96. Besides significance levels obtained $0.039(p<0.05)$. So the second hypothesis stated organizational culture effect significantly to current motivation proved to be true. Results of the research it supports research conducted by According to research conducted by Brahmasari and Suprayetno (2008), proving that the organizational culture positive and significant effect against the job satisfaction of employees. It is also supported by research conducted Robbins (2003) in the Arif (2010) States that culture is a system of shared meaning shared by members of the organization which distinguish the organization from other organizations. In the study shows that organizational culture also affects the performance of the employee.

\section{The motivation significant effect on the employee performance}

The results of the variable parameter estimation of motivation on performance of employees on the basis of indicators show significant results with a value of CR -5.351 . This value is greater than 1.96. Besides significance levels obtained $0.006(\mathrm{p}<0.05)$. So the third hypothesis stated motivation effect significantly to current employees performance proved to be true. The results of parameter estimation variables work motivation on performance indicators based on employee charge indicators will show significant results with a value of CR-5.351 $(<1.96)$ and extent of significance $0.000 \quad(\mathrm{p}<0.05)$ suggests that the motivation of working effect significantly to performance proven employees. Results of the research it supports research conducted by Arifin (2015) which concluded that motivation effect significant on performance of employees. As such, owned a high motivation of employees in work will generate a high outsourcing employee performance also.

\section{Conclusion}

\section{CONCLUSIONS AND SUGGESTION}

Based on the deliberations of the conclusion can be made as follows

1. Leadership positive and significant effect against employee motivation University of Nahdlatul Ulama Surabaya Indonesia.

2. Organizational culture positive and significant effect against employee motivation University of Nahdlatul Ulama Surabaya Indonesia.

3. Motivation positive and significant effect against employee performance University of Nahdlatul Ulama Surabaya Indonesia. 


\section{Suggestion}

Based on the conclusions then recommended terms as follows:

1. Tthe need for support from the leadership of the highly influential the perceived performance of the employees. More support to make employees will be more convenient in respect of work and employees more accountable so as to maximize.

2. For further research, it is recommended to add a free variable so that it can better expand again to do the influence between leadership and organizational culture towards motivation and employee performance University of Nahdlatul Ulama Surabaya Indonesia is currently only as on and on further research it needs to be examined more.

\section{BIBLIOGRAPHY}

Arif, Rusdan, 2010. The influence of the Leadership and Organizational Culture on Performance of Employees. Theses published. Diponegoro University.

Arifin, H. M. 2015. The Influence of Competence, Motivation, and Organisational Culture to High School Teacher Job Satisfaction and Performance. International Education Studies; Vol. 8, No. 1.

Eka Idham Lip K Lewa and Subowo, 2005, Influence Leadership, Physical work environment, Employee Performance and Compensation Against PT. Pertamina (PERSERO) Regional Operations Upstream to the West Java, Cirebon, Synergy Special Edition on Human Resources, 2005.

Ferdinand, A. 2000. Structural Education Modelling in research management. The first edition. Semarang: Universitas Diponegoro.

Gamal, A. and Soemantri, A.I., 2017. The Effect of Balanced Scorecard on the Private College Performance (Case Study at the University of WR Supratman Surabaya). Archives of Business Research, 5(5), 126-134.

Ghozali, Imam, 2007, Applications of Multivariate analysis with SPSS Program: University of Diponegoro, Semarang

Gibson, Ivancevish, Donelly, 2004. Organizations Behaviour, Boston.

Handoko, T Hani. 2001. Management Human Resources And Personnel. Yogyakarta: GADJAH MADA UNIVERSITY BPFE.

Handoko T Hani. 2001. Management Human Resources And Personnel. Yogyakarta: Gadjah Mada University BPEF. Luthans, Fred. 2006. Organizations Behaviour, Edisi 10. Yogyakarta: Andi

Mangkunegara, Anwar Prabu, 2004. The Behavior and Culture of the Organization, first printing, Bandung: PT. Refika Aditama.

Mathis, R.L dan Jackson, J.H. 2002. Human Resource Management. Jakarta: Salemba Empat.

Narimawati, Umi and Munandar, Dadang. 2008. Theory and Practice of Sampling Techniques Using SPSS 15. Yogyakarta: Gava Media.

Rivai, and Basri. 2005. Human Resource Management For the Company from Theory to P\practice. First printing. Jakarta: PT Raja Grafindo Persada.

Robbins and Judge. 2009. Organizational Behaviour. Jakarta: Salemba Empat.

Robbins, P Stephen, Judge, A. Timothy 2015. Organizational Behaviour (sixteenth Ed.), Jakarta. Salemba Empat Simamora, Henry. 20049. Human Resources Management. Prints The Third. Yogyakarta: YPPKN.

Schein, H Edgar. 1992. Organizational Culture and Leadership, Second Edtion, Jossey Bass Publishers, San Francisco

Stoner, C.R. 1984. The Foundations of Business Ethics: Exploring the Relationship between Organizational Culture, moral Values and Actions. Advanced Management Journal, $\underline{54}, 38$ - 43.

Syahrum, Brahmasari, and Nugroho. 2016. Effect of Competence Organization Culture and Climate of Organization to the Organizational Commitmen, Job Satisfactions and The Performance of Employess in The Scope of Makasar City Government. 